This document is the accepted manuscript version of a published work that appeared in final form in the British Journal of Midwifery, copyright (c) MA Healthcare, after peer review and technical editing by the publisher. To access the final edited and published work see

https://doi.org/10.12968/bjom.2017.25.8.531

\title{
Coping with end-of-year assessments: a survival guide for pre- registration midwives
}

\begin{abstract}
The midwifery pre-registration programme of study is a demanding undertaking as it prepares students for the stressors and complexities of the role of the qualified midwife. Additionally, there are 'pinch points' during each academic year where the pressures of assessments both in practice and theory can lead to students feeling overwhelmed and unable to cope. Whilst multiple submissions due on or around the same time may seem excessive, with my 'academic's hat' on I can offer a justification for timings, namely students can't be assessed on what they haven't learned, which inevitably leads to a heavy assessment schedule towards the end of each academic year.

Previous articles have discussed the importance of student midwives' being supported to develop resilience during their training to cope with the increasing and ever more complex demands of their chosen career (Power, 2016) and have provided 'Survival Guides' to help navigate the early stages of the course (Power, 2015a) and for first labour ward placements (Power, 2015b). More recently university support systems for student midwives with additional needs have been explored (Power and Murray, 2017). This article will complement existing literature by suggesting self-help techniques such as relaxation, exercise and making use of existing support networks, along with signposting to useful online resources for students to access during particularly stressful times of their training.

Keywords: resilience; assessments; midwifery pre-registration; emotional support;
\end{abstract}

\section{Introduction}

This is a particularly busy time of year in the academic calendar, with student midwives coming towards the end of assessed clinical placements whilst preparing for oral and written assessments. Standard 15 of the Standards for Pre-registration Midwifery Education (NMC, 2010:20) states:

'Clinical practice must be graded and be counted as part of the academic award. All outcomes within a progression point period (for example an academic year) have to be achieved and confirmed within 12 weeks of entering the next academic level. All assessments must be completed 
and have been passed prior to successful completion of the programme. This is designed to confirm that the student has the theoretical knowledge, practical skills and attitude to achieve the standards required for entry to the midwives' part of the register.'

Students must pass all assessments to be able to progress to the next year of their programme of study or to be admitted to the register if they are finalists. The aim of this article is to offer students suggestions on how to cope with the additional stressors of upcoming assessments. It is also hoped that by developing coping strategies as a student, individuals will further develop such strategies beyond registration to cope with the complexities and uncertainties of the clinical environment.

\section{Make use of your support network}

- Let friends and family know how you're getting on and feeling. Sharing a problem can help and talking through things with someone you trust can be helpful.

- Find out who your Personal Academic Tutor (PAT) is early on in the course and arrange to meet or speak to them regularly, particularly when on clinical placements when you are more likely to feel isolated. If required you can find out more about your University's student support services. This could include things like counselling and mental health advisor support for students.

- Fellow student midwives on your course can provide informal support. Sharing your experience of things that happened on placement or difficulties with academic work can help to put things in perspective and foster a sense of community.

- Use resources on the Internet, eg:

The Mind Tools website can advise on managing stress

https://www.mindtools.com

The Stressbusting website provides information on

techniques to manage stress

http://www.stressbusting.co.uk/treatments

- Talk to your GP if you are finding things difficult.

\section{Give yourself a break/time to relax}

- Try and set aside clear times for study and leisure. This gives you goals to work towards and can provide you with enough down time to relax and recharge your batteries. 
- Be clear with family about your set study and leisure times and help develop a shared routine where possible.

- Set yourself clear goals and take time to reflect and reward yourself when things have gone well.

- Make time for friends. Meeting up with friends regularly can help you to feel less isolated.

- When things don't go well or when you make a mistake, try and accept this and don't put extra pressure on yourself by being overly self-critical.

- If you're struggling with an assignment then take a break, go outside, visit a friend or just do something non study related for a bit. Set a time when you will return to your work so you can take a clear break without feeling guilty.

- Set longer term goals and rewards where possible to help keep you motivated. This could be a summer holiday or new gadget that you have been saving up for.

- Be aware of controllable factors that can add to feelings of stress. For example, you may be aware that listening to/watching the news several times a day, every day, makes you feel worse. You could watch or listen to a weekly review show to stay informed but possibly less stressed!

- "Resolve conflicts, if you can. Although this can sometimes be hard, speaking to a manager, colleague or family member about problems in your relationship with them can help you find ways to move forward." (Mind official website, 2017)

\section{Look after your physical health}

- Walk, run, cycle, swim... do anything that makes you more physically active. Your University will have lots of different sports teams available to join. Many running events like Park Run are free and open to runners of all ages and abilities.

- Develop your interests and hobbies. Making time for an activity can be a good way to reduce pressure and meet new people. Universities have hundreds of different societies that you can join to meet like-minded people who share your hobby/passion.

- Establishing clear routines between work and play may also help you to get to bed on time. "Being well-rested can increase your ability to deal with difficult situations." (Mind official website, accessed $11^{\text {th }}$ May 2017)

- Try and eat as healthily as you can. When stressed, it can be easy to eat too much junk food or to eat too little food in general.

- Set aside time for activities that help you relax. You could look in to certain relaxation techniques (e.g. mindfulness, breathing exercises) or just make time for doing things you enjoy. 


\section{Key Points}

- Take pride in your role as a student midwife and the high quality care you provide.

- Be clear to others if you feel they are making unrealistic or unreasonable demands on you. This can be important in setting clear expectations for caseloads and the amount of work you are able to realistically do.

- Accept that you will make mistakes and remember you will probably learn more from experiences where things haven't gone well.

\section{Conclusion}

The midwifery pre-registration programme of study is demanding both physically and emotionally. Students are required to be clinically competent, commensurate with their level of training and are also expected to meet high academic expectations: to be critical thinkers and reflective practitioners in line with the requirements of the Code (NMC, 2015). Students should be supported during their studies to develop resilience and this is particularly important during assessment periods. It is hoped that this Survival Guide will be a useful resource in their self-help toolkit.

Acknowledgement: Resource compiled by J Murray

\section{References}

British Broadcasting Corporation (BBC) (2017) Is Resilience written in our DNA? $B B C$ [online]. Available from: http://www.bbc.co.uk/guides/z2qxfrd [Accessed 12th May 2017]

Mind.org.uk (March 2015). Mind Official Website. [online] Available at https://www.mind.org.uk [Accessed $11^{\text {th }}$ May 2017].

NHS Choices (April 2016). NHS Website [online]. Available from: www.nhs.uk/conditions [Accessed 12th May 2017].

Nursing and Midwifery Council (NMC) (2015) The Code: professional standards of practice and behaviour for nurses and midwives. NMC [online]. Available from: https://www.nmc.org.uk/globalassets/sitedocuments/nmcpublications/nmc-code.pdf. [Accessed $15^{\text {th }}$ May 2017] 
Nursing and Midwifery Council (NMC) (2010) Standards for pre-registration midwifery education. NMC [online]. Available from:

https://www.nmc.org.uk/globalassets/sitedocuments/standards/nmc-standardsfor-preregistration-midwifery-education.pdf. [Accessed $15^{\text {th }}$ May 2017]

Power A, Murray J (2017) How can universities 'ASSIST' student midwives with additional needs to achieve? British Journal of Midwifery 25 (4) 258-260

Power A (2016) Midwifery in the $21^{\text {st }}$ century: are students prepared for the challenge? British Journal of Midwifery 24 (1) 66-68

Power A (2015) Welcome to practice: a guide for the first labour ward placement. British Journal of Midwifery 23 (12) 902-903

Power A (2015) Welcome to class: a survival guide for commencing student midwives. British Journal of Midwifery 23 (10) 746-748

\section{Authors:}

Alison Power (Senior Lecturer in Midwifery, The University of Northampton) Jonathan Murray (ASSIST Officer, The University of Northampton) 